V. N. Fedorov ${ }^{1}$, associate Professor, Candidate of Technical Sciences, V. V. Kikot ${ }^{2}$, student, N. I. Shtefan ${ }^{3}$, associate Professor, Candidate of Technical Sciences

\title{
DETERMINATION OF MERIDIAN POSITION BY A TWO-STEP GROUND GYROCOMPASS IN EESTHETICAL ROTOR POSITIONING
}

Ua Протиріччя між точністю і часом визначення площині географічного меридіана істотно ослабло із появою автоматичних гірокомпасів і алгоритмічних методів обробки інформації із них. Зазначені методи дозволяють розширити спектр можливих режимів роботи гірокомпасів, використовуючи в тому числі й нетрадиційні. У статті розглядається автоматичний двоступеневий наземний гірокомпас, що працює у режимі природної зупинки ротора після його імпульсного розгону неелектричними засобами (пиропатрон, стиснене повітря тощо). Зазначений режим привабливий тим, що дозволяє в одному пуску ідентифікувати неконтрольований шкідливий момент навколо осі підвісу і істотно зменшити час вимірювання. 3 метою подальшого вдосконалення приладу запропоновано відмовитися від вимірювання поточного значення кінетичного моменту, а коефіцієнт загасання експоненційної функції ідентифікувати, спостерігаючи за азимутним рухом чутливого елемента приладу. Більш того, в статті показано, що можна не вимірювати початкове значення кінетичного моменту, замінивши вимір ідентифікацією цього параметра за спостереженнями за тим же азимутним рухом чутливого елемента. У цьому випадку відпадає необхідність у наявності на чутливому елементі яких би то ні було вузлів, пов'язаних 3 передачею електроживлення і електричних сигналів, чутливий елемент може бути виконаний як чисто механічний елемент, що несе на собі ротор, що обертається.

Для всіх розглянутих варіантів вимірювання (або ідентифікації) параметрів проведено машинне моделювання, яке підтвердило працездатність запропонованої методики.

Ru Противоречие между точностью и временем определения плоскости географического меридиана существенно ослабло с появлением автоматических гирокомпасов и алгоритмических методов обработки информации с них. Указанные методы позволяют расширить спектр возможных режимов рабо-

\footnotetext{
${ }^{1}$ Igor Sikorsky Kyiv polytechnic institute

${ }^{2}$ Igor Sikorsky Kyiv polytechnic institute

${ }^{3}$ Igor Sikorsky Kyiv polytechnic institute
} 
ты гирокомпасов, используя в том числе и нетрадиционные. В статье рассматривается автоматический двухстепенной наземный гирокомпас, работающий в режиме естественной остановки ротора после его импульсного разгона неэлектрическими средствами (пиропатрон, сжатый воздух и т.д.). Указанный режим привлекателен тем, что позволяет в одном пуске идентифицировать неконтролируемый вредный момент вокруг оси подвеса и существенно уменьшить время измерения. С целью дальнейшего совершенствования прибора предложено отказаться от измерения текущего значения кинетического момента, а коэффициент затухания экспоненциальной функции идентифицировать, наблюдая за азимутальным движением чувствительного элемента прибора. Более того, в статье показано, что можно не измерять начальное значение кинетического момента, заменив измерение идентификацией этого параметра по наблюдениям за тем же азимутальным движением чувствительного элемента. В этом случае отпадает необходимость в наличии на чувствительном элементе каких бы то ни было узлов, связанных с передачей электропитания и электрических сигналов, чувствительный элемент может быть выполнен как чисто механический элемент, несущий на себе вращающийся ротор.

Для всех рассмотренных вариантов измерения (или идентификации) параметров проведено машинное моделирование, подтвердившее работоспособность предложенной

\section{Introduction}

During construction of long tunnels, in surveying and military science, geodesy, cartography and many other spheres of human activity the question of determining the plane of geographical meridian in the place of measurement is relevant. Ground gyroscopic compasses (GC) - both three-step and two-step are used to solve it. The traditional confrontation between measurement accuracy and the time required to take measurements has resulted in a wide variety of technical solutions. The transition from measurement of the greatest deviations of a sensitive element (SE) of GC relative to a meridian plane (points of reversion) [1] to temporary methods [2], allowing to make measurements for time, essentially less than period of oscillations of SE, became the appreciable milestone in increase of efficiency of devices. A significant increase in the accuracy of measurements was achieved by applying the principle of dual-channel, which is realized in gyroscopy either by having two gyroscopes with oppositely directed vectors of kinetic moments [3], or by additional software turns of the PME during measurements [4,5]. The next step in improving the accuracy and speed of GC was the use of algorithmic methods [6], which allow solving the problem on the basis of the analysis of the current position of the PE during a given time interval. In [7] a method of determining the meridian during the acceleration of its rotor is proposed, which significantly reduces the measurement time, and in [8] the possibility of determining the meridian position by threestage GC in the mode of natural stop of the rotor is considered. 


\section{Task definition}

The purpose of this paper is to develop a method of determining the position of the meridian by two-step GC during natural - by exponential in time law - stopping of the rotor. Application of the mentioned technique, since it does not require transfer of electric power to the rotor in principle, will allow to refuse placing of electric drive elements on the rotor, and, what is very important, to refuse current leads, that is practically to eliminate mechanical connection between stationary and moving parts of GC. In this case, of course, it is necessary to solve the issue of instantaneous (pulse) acceleration of the rotor by other non-electrical - means. This can be, for example, the use of a squib, compressed water, or other means. In addition, the paper presents algorithms of information processing, which allow determining the meridian by the results of observation of GC, the rotor of which naturally stops.

\section{Statement of basic material and research}

The equation of motion of the PE of a two-stage GC, assuming that its suspension axis is set vertically, is as follows

$$
J \ddot{\alpha}+H \Omega_{2} \alpha=0,
$$

where $J$ is the moment of inertia of the PM relative to the axis of suspension, $\mathrm{H}$ is the kinetic momentum of the GC rotor, $\Omega \mathrm{r}$ is the horizontal component of the angular velocity of the Earth at the place of measurement, $\alpha$ is the current angle of deviation of the GC rotor axis from the north direction.

Assuming that the kinetic momentum of the rotor during the natural stopping changes according to the law

$$
H=H_{m} e^{-\lambda t},
$$

where $H_{m}$ is the initial value of the kinetic momentum, $\lambda$ is the decay index of the exponential function, $\mathrm{t}$ is the current time, taking into account the notation

$$
B=H_{m} \Omega_{2} J^{-1},
$$

we write equation (1) as follows:

$$
\ddot{\alpha}+B e^{-\lambda t} \alpha=0 .
$$

Introduce a new independent variable

$$
z=2 \lambda^{-1}\left(B e^{-\lambda t}\right)^{0,5},
$$

then with regard to the notations $\alpha^{\prime}=\frac{d \alpha}{d z} u \alpha^{\prime \prime}=\frac{d^{2} \alpha}{d z^{2}}$ equation (1) will take the form:

$$
z^{2} \alpha^{\prime \prime}+z \alpha^{\prime}+z^{2} \alpha=0
$$

Equation (6) is a Bessel equation and has a solution [9]:

$$
\alpha=C_{1} J_{0}(z)+C_{2} Y_{0}(z)
$$


where $C_{1}$ and $C_{2}$ are integration constants, $J_{0}$ and $Y_{0}$ are Bessel functions of the first and second orders, respectively, of "zero" order. Using the initial conditions

$$
z=z_{0}=>\alpha=\alpha_{0}, \alpha^{\prime}=\alpha_{0}^{\prime \prime}
$$

determine the integration constants $C_{1}$ and $C_{2}$, then, by performing simple transformations using the recurrence relations for Bessel functions, we finally write down the analytical law of motion of the PE of a two-stage GC at a natural rotor stop in the form

$$
\alpha=0,5 \pi z_{0}\left\{\alpha_{0}\left[J_{1}\left(z_{0}\right) Y_{0}(z)-J_{0}(z) Y_{1}\left(z_{0}\right)\right]+\alpha_{0}^{\prime}\left[J_{0}\left(z_{0}\right) Y_{0}(z)-J_{0}(z) Y_{0}\left(z_{0}\right)\right]\right\} .
$$

Keeping in mind that when the GC moves, the observed coordinate is the angle $\alpha-\alpha_{0}$, equation (9) can be represented as

$$
\alpha_{0} f_{1}\left(z, z_{0}\right)+\alpha_{0}^{\prime} f_{2}\left(z, z_{0}\right)=f_{3}\left(z, z_{0}\right),
$$

where $f_{1}\left(z, z_{0}\right)=J_{1}\left(z_{0}\right) Y_{0}(z)-J_{0}(z) Y_{1}\left(z_{0}\right)-2 \pi^{-1} z_{0}^{-1}$,

$$
\begin{aligned}
& f_{2}\left(z, z_{0}\right)=J_{0}\left(z_{0}\right) Y_{0}(z)-J_{0}(z) Y_{0}\left(z_{0}\right), \\
& f_{3}(z, z)=2\left(\alpha-\alpha_{0}\right) \pi^{-1} z_{0}^{-1} .
\end{aligned}
$$

If we assume that in the process of determining the position of the meridian plane the initial value of the kinetic moment $H_{\mathrm{m}}$ can be measured and the decay index of the exponential function $\lambda$ can be calculated from the analysis of the measured dependence (2), then the desired initial deviation $\alpha_{0}$ can be found by minimizing the functional

$$
F\left(\alpha_{0}, \alpha_{0}^{\prime}\right)=\Sigma\left[\alpha_{0} f_{1}\left(z, z_{0}\right)+\alpha_{0}^{\prime} f_{2}\left(z, z_{0}\right)-f_{3}\left(z, z_{0}\right)\right]^{2},
$$

i. e. as a result of solving a system of algebraic equations

$$
\begin{aligned}
& \alpha_{0} \sum f_{1}^{2}+\alpha_{0}^{\prime} \sum f_{1} f_{2}=\sum f_{1} f_{3}, \\
& \alpha_{0} \sum f_{1} f_{2}+\alpha_{0}^{\prime} \sum f_{2}^{2}=\sum f_{2} f_{3} .
\end{aligned}
$$

In order to confirm the efficiency of the proposed methodology, a computer simulation was carried out, the only difference being that not an analytical solution of equation (1) in the form of dependence (10) was used as a mathematical model of GK motion, but the result of the computer integration of equation (1). The scheme of the machine experiment is shown in fig. 1.

The two-stage GC simulator was a block for integrating the differential equation (1), taking into account the change in the kinetic momentum according to the law (2). Integration was performed at the following numerical values of parameters: $J=1,1607 * 10^{-3}, \mathrm{HMS}^{2} ; \Omega_{2}=3,65^{*} 10^{-5}, \mathrm{~s}^{-1} ; H_{m}=0,432$, HMs; $\lambda=$ $2.15^{*} 10^{-3}, \mathrm{~s}^{-1}$ and given initial conditions $\alpha_{0}=3,69 \pi / 540, \mathrm{rad} ; \dot{\alpha}_{0}=4,08 * 10^{-4}, \mathrm{~s}^{-1}$. The mathematical model of the GC was a similar block of integration of the same equation (1) with the same values of parameters, but the initial conditions of the GC PE motion were unknown. The range of their variation was set as follows: $\alpha_{0} \epsilon\left(-\frac{\pi}{60} ;+\frac{\pi}{60}\right)$, rad; a $\alpha_{0}^{\prime} \epsilon(-6 ;+6) * 10^{-4}, \mathrm{~s}^{-1}$. In the first approximation, the 
step when changing the parameter $\alpha_{0}$ was chosen $\Delta \alpha_{0}=\frac{\pi}{540}$, rad; and the step when changing the parameter $\dot{\alpha}_{0}$ was chosen $\Delta \alpha_{0}^{\prime}=10^{-4}, \mathrm{~s}^{-1}$. For each pair of parameters $\alpha 0$ and $\alpha 0(13 * 19=247$ combinations), the result of integration of the mathematical model was compared according to the least-squares method with the behavior of the GC simulator on the interval $t=0 / 200 \mathrm{sec}$ with step $\Delta t=1 \mathrm{sec}[10]$. The "unrelatedness" is presented in tab. 1.

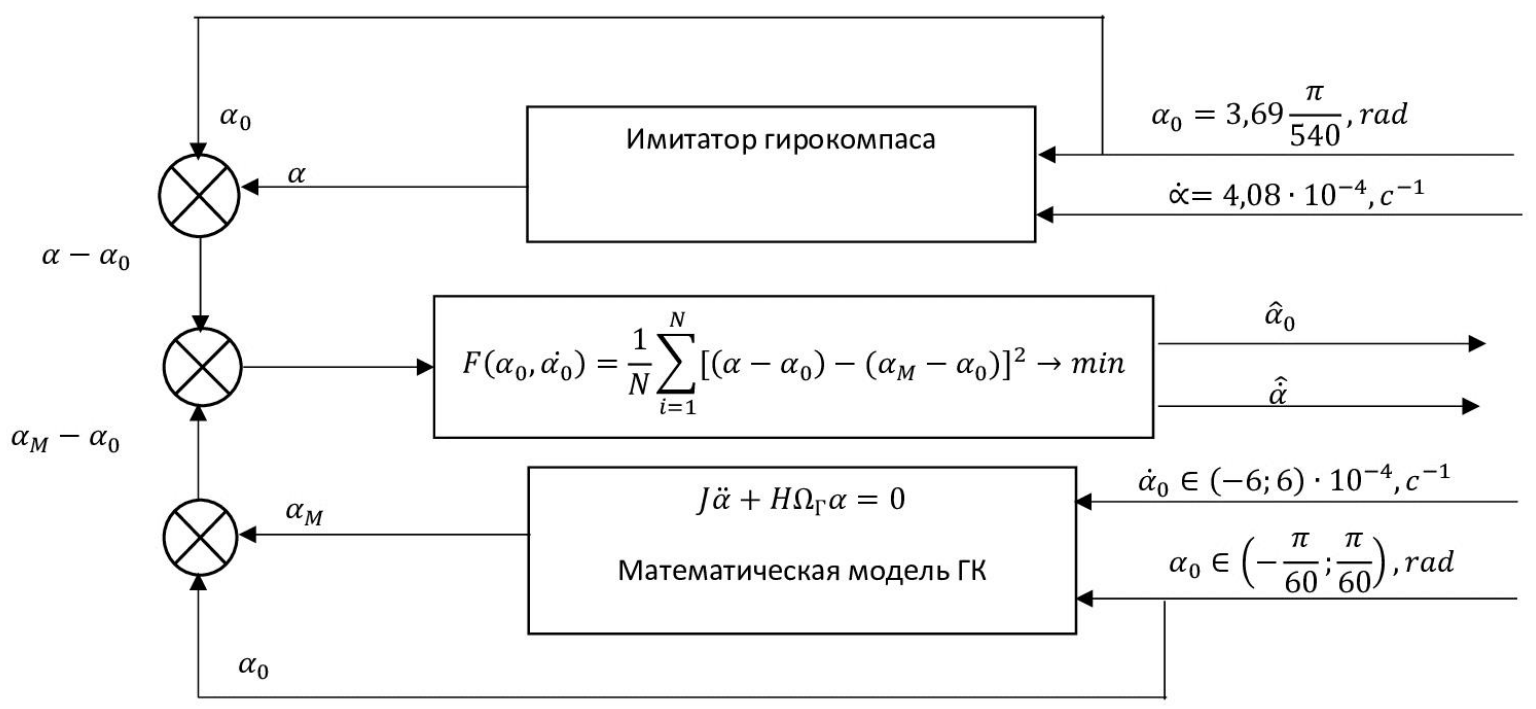

Fig. 1. Diagram of a machine experiment

Table 1.

Table of "unrelatedness".Identifiable parameters $-\alpha_{0}$ and $\dot{\alpha}_{0}$.

First approximation $F\left(\alpha_{0}, \dot{\alpha_{0}}\right) * 10^{-3}, \mathrm{rad}^{2}$

\begin{tabular}{|c|c|c|c|c|c|c|c|c|c|c|c|c|c|c|}
\hline & \multicolumn{13}{|c|}{$\dot{\alpha}_{0} * 10^{-4}, \mathrm{c}^{-1}$} \\
\hline & & -6 & -5 & -4 & -3 & -2 & -1 & 0 & 1 & 2 & 3 & 4 & 5 & 6 \\
\hline \multirow{14}{*}{ 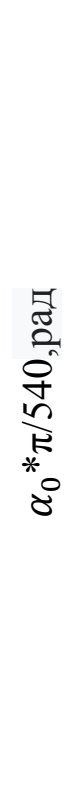 } & -9 & 41,8 & 41,6 & 41,4 & 41,2 & 41,1 & 40,9 & 40,7 & 40,6 & 40,5 & 40,3 & 40,2 & 40,1 & 40,0 \\
\hline & -8 & 38,7 & 38,5 & 38,3 & 38,1 & 37,9 & 37,7 & 37,6 & 37,4 & 37,3 & 37,2 & 37,0 & 36,9 & 36,8 \\
\hline & -7 & 35,5 & 35,3 & 35,1 & 34,9 & 34,7 & 34,6 & 34,4 & 34,3 & 34,1 & 34,0 & 33,9 & 33,8 & 33,7 \\
\hline & -6 & 32,4 & 32,2 & 32,0 & 31,8 & 31,6 & 31,4 & 31,2 & 31,1 & 30,9 & 30,8 & 30,7 & 30,6 & 30,5 \\
\hline & -5 & 29,3 & 29,1 & 28,8 & 28,6 & 28,4 & 25,1 & 28,1 & 27,9 & 27,8 & 27,6 & 27,5 & 27,4 & 27,3 \\
\hline & -4 & 26,2 & 26,1 & 25,7 & 25,5 & 25,3 & 25,1 & 24,9 & 24,8 & 24,6 & 24,5 & 24,3 & 24,2 & 24,1 \\
\hline & -3 & 23,2 & 22,9 & 22,6 & 22,4 & 22,2 & 22,0 & 21,8 & 21,6 & 21,4 & 21,3 & 21,2 & 21,1 & 21,0 \\
\hline & -2 & 20,1 & 19,8 & 19,5 & 19,3 & 19,0 & 18,8 & 18,6 & 18,4 & 18,3 & 18,1 & 18,0 & 17,9 & 17,8 \\
\hline & -1 & 17,2 & 16,8 & 16,5 & 16,2 & 16,0 & 15,7 & 15,5 & 15,3 & 15,1 & 15,0 & 14,8 & 14,7 & 14,6 \\
\hline & 0 & 14,3 & 13,9 & 13,5 & 13,2 & 12,9 & 12,6 & 12,4 & 12,1 & 12,0 & 11,8 & 11,7 & 11,6 & 11,5 \\
\hline & 1 & 14,3 & 11,1 & 10,7 & 10,3 & 9,9 & 9,6 & 9,3 & 9,0 & 8,8 & 8,6 & 8,5 & 8,4 & 8,3 \\
\hline & 2 & 9,3 & 8,7 & 8,2 & 7,6 & 7,1 & 6,7 & 6,3 & 6,0 & 5,7 & 5,5 & 5,3 & 5,2 & 5,2 \\
\hline & 3 & 7,5 & 6,9 & 6,3 & 5,6 & 5,0 & 4,4 & 3,8 & 3,2 & 2,7 & 2,4 & 2,1 & 2,1 & 2,2 \\
\hline & 4 & 5,9 & 5,3 & 4,7 & 4,1 & 3,5 & 2,9 & 2,3 & 1,8 & 1,3 & 1,0 & 0,9751 & 1,2 & 1,7 \\
\hline
\end{tabular}




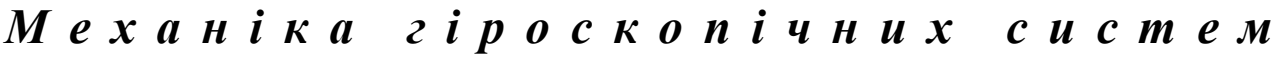

\begin{tabular}{|r|r|r|r|r|r|r|r|r|r|r|r|r|r|}
\hline \hline & \multicolumn{10}{|c|}{$\dot{\alpha}_{0} * 10^{-4}, \mathrm{c}^{-1}$} \\
\cline { 2 - 15 } & \multicolumn{1}{|c|}{-6} & -5 & -4 & -3 & -2 & -1 & 0 & 1 & 2 & 3 & 4 & 5 & 6 \\
\hline 5 & 6,3 & 5,9 & 5,5 & 5,1 & 4,8 & 4,5 & 4,3 & 4,1 & 4,0 & 4,0 & 4,1 & 4,2 & 4,5 \\
6 & 8,3 & 8,1 & 7,8 & 7,6 & 7,4 & 7,3 & 7,2 & 7,1 & 7,1 & 7,2 & 7,3 & 7,4 & 7,6 \\
7 & 10,9 & 10,7 & 10,6 & 10,5 & 10,4 & 10,3 & 10,3 & 10,3 & 10,3 & 10,3 & 10,4 & 10,6 & 10,7 \\
8 & 13,7 & 13,6 & 13,5 & 13,4 & 13,4 & 13,4 & 13,4 & 13,4 & 13,4 & 13,5 & 13,6 & 13,7 & 13,9 \\
9 & 16,7 & 16,6 & 16,5 & 16,5 & 16,5 & 16,5 & 16,5 & 16,5 & 16,6 & 16,7 & 16,8 & 16,9 & 17,0
\end{tabular}

As can be seen from Table1, the smallest value of unrelatedness, equal to $F_{1}\left(\alpha_{0}, \alpha_{0}^{\prime}\right)=0,9751 * 10^{-3}, \operatorname{rad}^{2}$ occurs in the case of $\alpha_{0}=4 \pi / 540, \mathrm{rad}$; and $\dot{\alpha}_{0}=4 * 10^{-4}, \mathrm{~s}^{-1}$. Further, near the point with the minimum "unrelatedness" $\mathrm{F}_{1}\left(\alpha_{0}, \alpha_{0}\right)$ the range was chosen $\alpha_{0} \in(3,0 \pi / 540 ;+5,9 \pi / 540)$,rad, and $\dot{\alpha}_{0} \epsilon$ $(3,0 ; 5,9)^{*} 10^{-4}, \mathrm{~s}^{-1}$, stepom $\Delta \alpha_{0}=0,1 \pi / 540, \mathrm{rad} ;$ and $\Delta \dot{\alpha}_{0}=10^{-5}, \mathrm{~s}^{-1}$ was calculated in the second approximation. Its minimum value was $\mathrm{F}_{2}\left(\alpha_{0}, \alpha_{0}\right)=0,362 * 10^{-4}, \operatorname{rad}^{2}$ at $\alpha_{0}=3,7 \pi / 540$,rad; and $\dot{\alpha}_{0}=4,1 * 10^{-4}, \mathrm{~s}^{-1}$. In the third approximation the range was calculated $\alpha_{0} \in(3.60 \pi / 540 ; 3,79 \pi / 540)$, s Stepom $\Delta \alpha_{0}=0.01 \pi / 540, \mathrm{rad}$, и $\dot{\alpha}_{0} \epsilon$ $(4.00 ; 4.29) * 10^{-4}, \mathrm{~s}^{-1}$, with stepom $\Delta \dot{\alpha}_{0}=10^{-6}, \mathrm{~s}^{-1}$. «Unrelatedness» $\mathrm{F}_{3}\left(\alpha_{0}, \alpha_{0}\right)$ in the third approximation within the chosen calculation accuracy is absent at $\alpha_{0}=3,69 \pi / 540, \mathrm{rad} ;$ and $\dot{\alpha}_{0}=4,08 * 10^{-4}, \mathrm{~s}^{-1}$. The coincidence of the parameters $\alpha_{0}$ and $\dot{\alpha}_{0}$ found in the process of identification with the specified initial conditions at the input of the GC simulator testifies to the operability of the proposed methodology.

The above-mentioned methodology of meridian determination assumes that the parameters $\mathrm{Hm}$ and $\lambda$, which characterize the process of natural rotor stopping, are known. In order to provide the mentioned condition, it is necessary to transfer the information about the current rotor speed from PE to the device body during the whole measurement interval, which imposes additional mechanical perturbations on the motion of the sensing element. Therefore, such variant of the proposed technique is interesting: the latter is measured in the charr acterized position of the PE, the value of the angular velocity of rotation of the rotor, which uniquely determines the initial value $\mathrm{Hm}$ of the kinetic momentum during its natural stopping, and the coefficient $\lambda$ is determined by its identification along with the initial conditions $\alpha_{0}$ и $\dot{\alpha}_{0}$. Let's simulate the proposed variant: let's assume that in the mathematical model of GC, in addition to the initial conditions $\alpha_{0}$ and $\dot{\alpha}_{0}$ there is a third unknown parameter, $\lambda$. We set the range of possible deviations $\lambda$ within $50 \%$, i.e. approximately $\lambda \in(1.00 ; 3.00) * 10-3$, s- 1 . Let us find the minimum value of the "unrelatedness" F1 $(\alpha 0, \dot{\alpha} 0, \lambda)$ by comparing the simulator and mathematical model motion for such $(13 * 19 * 21=5187$ combinations) parameter values:

$$
\begin{aligned}
& \text { 1) } \alpha_{0} \epsilon\left(-\frac{\pi}{60} ;+\frac{\pi}{60}\right), \mathrm{s} \text { stepom } \Delta \alpha_{0}=\frac{\pi}{540}, \mathrm{rad} \\
& \text { 2) } \alpha_{0}^{\prime} \epsilon(-6 ;+6) * 10^{-4}, \mathrm{~s}^{-1} \mathrm{~s} \quad \Delta \alpha_{0}^{\prime}=10^{-4}, \mathrm{~s}^{-1}
\end{aligned}
$$


3) $\lambda \in(1.00 ; 3.00) * 10^{-3}, \mathrm{~s}^{-1}$ stepom $\Delta \lambda=0,1 * 10^{-3}, \mathrm{~s}^{-1}$.

We got a minimum of " unrelatedness " $\Phi_{1}\left(\alpha_{0}, \dot{\alpha}_{0}, \lambda\right)=0,9718 * 10^{-3}, \mathrm{rad}^{2}$ with parameter values $\alpha_{0}=4 \pi / 540, \mathrm{rad} ; \dot{\alpha}_{0}=4 * 10^{-4}, \mathrm{~s}^{-1} ; \lambda=2,2^{*} 10^{-3}, \mathrm{~s}^{-1}$. We search for the minimum in the vicinity of this point, i.e. we carry out the second and then the third approximation, as we did in the case of searching for the minimum by two parameters $\alpha_{0}$ and $\dot{\alpha}_{0}$. The resulting data is summarized in a tab. 2 .

Table 2.

Finding the minimum for the three identifiable parameters $\alpha_{0}, \dot{\alpha}_{0}$, and $\lambda$

\begin{tabular}{|c|c|c|c|c|}
\hline & \multicolumn{3}{|c|}{ Parameters } & «Unrelatedness», \\
\cline { 2 - 4 } & $\alpha_{0}, \mathrm{rad}$ & $\dot{\alpha}_{0}, \mathrm{~s}^{-1}$ & $\lambda, \mathrm{s}^{-1}$ & \\
\hline
\end{tabular}

First approximation

$\begin{array}{lcccc}\text { Range } & (-9 ;+9) \pi / 540 & (-6 ;+6) * 10^{-4} & (1,0 ; 3,0) * 10^{-3} & \\ \text { Step } & \pi / 540 & 10^{-4} & 10^{-4} & 0,9718 * 10^{-3} \\ \text { The "best" } & 4 \pi / 540 & 4 * 10^{-4} & 2,2 * 10^{-3} & \end{array}$

score

Second approximation

$\begin{array}{lcccc}\text { Range } & (3 ; 5) \pi / 540 & (3 ; 5) * 10^{-4} & (2.1 ; 2,3) * 10^{-3} & \\ \text { Step } & 0,1 * \pi / 540 & 10^{-5} & 10^{-5} & 0,362 * 10^{-4} \\ \text { The "best" } & 3,7 \pi / 540 & 4,1 * 10^{-4} & 2,14 * 10^{-3} & \\ \text { score } & & & \end{array}$

\begin{tabular}{|c|c|c|c|}
\hline \multirow[b]{2}{*}{ Range } & \multicolumn{3}{|c|}{ Third approximation } \\
\hline & $\begin{array}{c}(3,6 \\
3,8) \pi / 540\end{array}$ & $(4,01 ; 4,20) * 10^{-4}$ & $\begin{array}{c}(2,131 ; \\
2,160) * 10^{-3}\end{array}$ \\
\hline Step & $0,01 * \pi / 540$ & $10^{-6}$ & $10^{-6}$ \\
\hline The "best" & $3,69 \pi / 540$ & $4,08 * 10^{-4}$ & $2,150 * 10^{-3}$ \\
\hline
\end{tabular}

Analysis of table 2 shows that the proposed methodology can also be applied in the case where the value of the coefficient $\lambda$ is unknown; it, as well as the initial conditions of motion $\alpha_{0}$ и $\dot{\alpha}_{0}$ can be identified by observing the azimuthal motion of the GC PE.

However, an ideal option would be to abandon the measurement of the initial value $\mathrm{Hm}$ of the value of the kinetic momentum of the $\mathrm{HK}$, and replace the measurement with the identification of the specified parameter. In this case, the construction of the device would be significantly simplified, since there would be no need for its electrical part. Let us simulate the measurement process in this case. Let us assume that the initial value of kinetic momentum Hm may differ from the declared value for the given gyro-motor up to $25 \%$, i.e. lies in the range $\mathrm{Hm} \in(0,34 ; 0,54)$, Nms. Let's carry out the procedure of searching for the min- 
imum of "unconformity" of the output signal of the simulator and the mathematical model of the HK in the conditions when there is no information about the exact values of the parameters $\alpha_{0}, \dot{\alpha}_{0}, \lambda$ и $\mathrm{H}_{\mathrm{m}}$. Let us make three approximations in accordance with the methodology outlined above. The results of the four parameter identification procedure are summarized in table 3.

Table 3.

Finding the minimum for the four identifiable parameters $\alpha_{0}, \dot{\alpha}_{0}, \lambda$ и $\mathrm{H}_{\mathrm{m}}$

\begin{tabular}{|c|c|c|c|c|c|}
\hline & \multicolumn{4}{|c|}{ Parameters } & \multirow{2}{*}{ 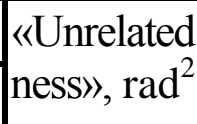 } \\
\hline & $\alpha_{0}, \mathrm{rad}$ & $\dot{\alpha}_{0}, \mathrm{~s}^{-1}$ & $\lambda, \mathrm{s}^{-1}$ & $\mathrm{H}_{\mathrm{m}}, \mathrm{s}^{-1}$ & \\
\hline
\end{tabular}

First approximation

$\begin{array}{lccccc}\text { Range } & (-9 ;+9) \pi / 540 & (-6 ;+6) * 10^{-4} & (1,0 ; 3,0) * 10^{-3} & (0,34 ; 0,54) & \\ \text { Step } & \pi / 540 & 10^{-4} & 10^{-4} & 10^{-2} & 0,974 * 10^{-3} \\ \text { The "best" } & 4 \pi / 540 & 4 * 10^{-4} & 2,2 * 10^{-3} & 0,43 & \\ \text { score } & & & & & \end{array}$

Second approximation

$\begin{array}{lccccc}\text { Range } & (3 ; 5) \pi / 540 & (3 ; 5) * 10^{-4} & (2,1 ; 2,3) * 10^{-3} & (0,42 ; 0,44) & \\ \text { Step } & 0,1 * \pi / 540 & 10^{-5} & 10^{-5} & 10^{-3} & 0,362 * 10^{-4} \\ \text { The "best" } & 3,7 \pi / 540 & 4,1 * 10^{-4} & 2,14 * 10^{-3} & 0,432 & \end{array}$

score

Third approximation

$\begin{array}{lccccc}\text { Range } & (3,6 ; 3,8) \pi / 540 & (4,01 ; 4,2) * 10^{-4} & (2,131 ; 2,160) * 10^{-3} & (0,431 ; 0,433) & \\ \text { Step } & 0,01 * \pi / 540 & 10^{-6} & 10^{-6} & 10^{-4} & 0,0 \\ \text { The "best" } & 3,69 \pi / 540 & 4,08 * 10^{-4} & 2,150 * 10^{-3} & 0,4320 & \\ \text { score } & & & & & \end{array}$

As can be seen from table 3, the position of the geographic meridian plane by two-step GC can also be found when four parameters - the initial conditions - are unknown before the start of measurement $\alpha_{0}$ и $\dot{\alpha}_{0}$ motion of the PM of the GC and the parameters $\lambda$ and Hm, which characterize the process of natural stopping of the rotor. This is evidenced by almost complete coincidence of the parameters found as a result of identification with their set values, as well as "zero" value of the "misalignment" obtained in the third approximation.

\section{Conclusions}

1. The paper considers an automatic two-step gyrocompass, which allows to determine the plane of geographic meridian by information about the current position of the sensitive element of GC in the azimuth. It is proposed to analyze the movement of PE in the mode when the angular velocity of the rotor of the device naturally decreases (the rotor is stopped). The choice of such mode is not accidental. It can significantly reduce the time of measurements, 
because the implementation of pulse acceleration of the rotor will allow to refuse the traditional operation of acceleration of the rotor, which requires a certain time. Besides, information gathering in the process of natural stopping of the rotor will allow to refuse in principle from mechanical connection between PE and the body of the device, which will lead to increase of accuracy of measurements.

2. The paper discusses three sets of parameters to be identified:- two unknowns: the initial conditions of motion $\alpha_{0}$ и $\dot{\alpha}_{0}$. The initial value $\mathrm{Hm}$ of the $\mathrm{HC}$ kinetic momentum is measured at the time of PE disentanglement, and the decay index $\lambda$ of the exponential function is calculated on the basis of the analysis of the current measured values $H=H(t)$ kinetic momentum;- the unknowns are three: $\alpha_{0}$ and $\dot{\alpha}_{0}$ and the decay index $\lambda$ of the exponential function. The current values of $H=H(t)$ of the kinetic momentum are not measured, except for the initial value of Hm at the moment of PE disarticulation; - there are four unknowns: the initial conditions of motion $\alpha_{0}$ and $\dot{\alpha}_{0}$, the decay parameter $\lambda$ of the exponential function and the initial value $\mathrm{Hm}$ of the kinetic momentum. It is shown that, in all three cases mentioned above, it is possible to identify the corresponding unknown parameters, and, first of all, the initial condition $\alpha 0$ of motion along the coordinate, by observing only the azimuthal motion of the HQ PE.

3. Machine simulation of the proposed algorithms for processing the information on the azimuthal motion of PE, confirmed the performance of the proposed methodology.

\section{References}

1. Sergeev M. A. Ground gyrocompasses / M. A. Sergeev - M.: Mashinostroenie, $1969 .-232 \mathrm{p}$.

2. Voronkov N. N. Gyroscopic orientation / N. N. Voronkov, V. V. Kutyrev, N. M. Ashimov - Moscow: Nedra, 1980 . - 296 p.

3. Odintsov A. A. Theory and calculation of gyroscopic devices / A. A. Odintsov - Kiev.: Vishcha school, 1985. - 392 p.

4. Lysenko A. S. Self-compensating strapdown gyroclinometer for continuous shooting of wells of arbitrary orientation: dis. for the competition degrees of cand. tech. Sciences: special. 11/05/03 «Navigation Devices». St. Petersburg, 2017 .- 170 p.

5. Zbrutsky O. V., Dovgopoliy A. S., Nesterenko O. I., Grigoryev V. M. «Gyrocompasses for navigation and guidance.» Monograph. NTUU "KPI im. Igor Sikorsky», 2017, 198 p.

6. Rakhmuni M. Algorithmic methods to improve the accuracy of the corrected gyroscopic compass: Author. dis ... cand. tech. Sciences: 05.11.03 / M. Rakhmuni; Nat tech. University of Ukraine "Kiev. Polytechnic. Institute". - K., 2003. - 19 p. 
7. Fedorov V. N. The methodology for determining the plane of the geographical meridian by the ground pendulum gyrocompass in the mode of exponential acceleration of its rotor / V. N. Fedorov, B. Yu. Ivanov, A. Yu. Olefir // Mechanics of gyroscopic systems. - 2015. - No. 30 p. 42-48. DOI: http://dx.doi.org/10.20535/0203-377130201569529

8. Fedorov V. M. Method of determining the position of the geographical meridian by a three-stage pendulum gyrocompass during the natural stop of its rotor./V. M. Fedorov, B. V. Gerik, Ya. Yu. Lukomsky, N. I. Stefan // Young scientist №6 (33), 2016. p. 205-208,

9. Kamke E. Handbook of ordinary differential equations / E. Kamke - M .: Nauka, 1971. - 576 p.

10.Kalitkin N. N. Numerical methods / N. N. Kalitkin - S.-Pb., BHVPetersburg, 2014. $-592 \mathrm{p}$. 